\title{
Survey and Antimicrobial Activity Study of Ethnomedicinal Plants in Selected Districts of North Shewa Zone, Oromia, Ethiopia
}

\author{
Gezahegn Faye (D) \\ Tadesse Birhanu ${ }^{2}$ \\ Tolosa Belete 3 \\ 'Department of Chemistry, College of \\ Nature Sciences, Salale University, Fiche, \\ Oromia Regional State, Ethiopia; \\ ${ }^{2}$ Department of Animal Science, College \\ of Agriculture and Natural Resources, \\ Salale University, Fiche, Oromia Regional \\ State, Ethiopia; ${ }^{3}$ Department of Biology, \\ College of Nature Sciences, Salale \\ University, Fiche, Oromia Regional State, \\ Ethiopia
}

Background: The emergency of multidrug resistance due to the global burden of infectious diseases and drug misuse leads to an urgent identification of new medicines from medicinal plants. The study was designed to perform the documentation of ethno-medicinal plants usage, extraction, phytochemical screening and antimicrobial activities of the herbal extracts. Methods: A cross-sectional study design was conducted in this study. Maceration of plant extraction, phytochemical screening and disc diffusion method for antimicrobial activity tests were employed.

Results: The results of the study indicated that Euphorbiaceae, Lamiaceae and Sapindaceae plant families have commonly used for the treatment of infectious diseases in the study areas. The antimicrobial activity test results indicated that Ostegia integrifolia Benth which was extracted with chloroform solvent showed equivalent inhibition zone as compared to standard drug, gentamicin. All the extracts could be considered as broad spectrum, have strong inhibition against $E$. coli, $K$. pneumoniae, S. aureus, $P$. aeruginosa and C. albicans. All extracts against $C$. albicans were also revealed strong inhibition activity as compared to fungal standard drug, contamazole.

Conclusion: Phytochemical screening showed the existence of secondary metabolites in the studied plants and thus, supports the traditional healers' claim of such plants use for the treatment of diseases. The study also concluded that chloroform extracts of all plants showed promising antimicrobial activities against $K$. pneumonia, and $C$. albicans. Therefore, further in vitro and vivo antimicrobial activity study of chloroform extracts against these bacterial and fungal strains were recommended. Moreover, isolation and structural elucidation of bioactive compounds from chloroform extracts were also recommended.

Keywords: antimicrobial activity, Ethiopia, maceration method, medicinal plants, North Shewa zone, phytochemical screening

\section{Introduction}

Plants are a good source of new medicines so that searching for the medicines are well justified. Plants are the only sources of therapeutics for nearly $80 \%$ of human population in developing country. ${ }^{1}$ Hence, human being has used plants to treat common infectious diseases, and some of the traditional medicines are still part of the habitual treatment of various diseases. ${ }^{2}$ Ethiopia has diverse flora and about 80 to $90 \%$ of its population relies on traditional medicine to meet their primary health care needs. ${ }^{1-3}$ Traditional health practitioners have made remedies from plants that play an important role in the health of millions of people. Ethno-medicinal studies on traditional knowledge, folk beliefs, skills, methods and practices used for the
Correspondence: Tadesse Birhanu Tessema

Email drbirhan@yahoo.com 
treatment of ailments. ${ }^{4}$ It offers medicines due to cultural acceptability, efficacy against certain diseases, economic affordability and locally available than pharmacotherapy. ${ }^{5}$

The medicinal value of plants like antimicrobial, anticancer, anti-inflammatory, antidiabetic, antioxidant, antidiuretic and etc. mainly depends on the secondary metabolites and the most important bioactive compounds of plants are alkaloids, saponins, flavonoids, tannins, sterols and phenolic compounds. ${ }^{6}$ In general, natural products are particularly good at providing many new chemical structures that no chemist would dream of synthesizing. For example, the anti-malarial drug artemisinin containing an extremely unstable-looking trioxane, ring-one of the most unlikely structure to have appeared in recent years. ${ }^{7}$

The emergence of drug resistance becomes the global health threat that involves all major microbial pathogens and antimicrobial drugs. ${ }^{8}$ It is difficult to treat and is responsible for a variety of infectious diseases. Bacterial and fungal pathogens have evolved numerous defense mechanisms against antimicrobial agents, and resistance to older and newly produced drugs is on the rise. As a result; scientific interest in medicinal plant has multiplied in recent times due to increased efficiency of new plant derived drugs and rising concerns about the side effects of modern medicine. Hence, the need to looking for new molecular structures as lead compounds from the plant kingdom. ${ }^{9}$

A few studies conducted in some African countries also indicated that herbal medicines used to treat infectious diseases. ${ }^{10-13}$ Similar studies that were also conducted on a wider range of Ethiopian plants revealed that are being used in the treatment of wounds, malaria and other diseases in the traditional health care system of the country. ${ }^{14-18}$ The studies which were conducted around the border area of North Shewa zone, Oromia, Ethiopia like Ankober district, ${ }^{19}$ Ada'a district, ${ }^{20}$ and around Fitche town, ${ }^{21}$ indicated the existence of large number of ethno medicinal plants associated with indigenous knowledge.

However, there was no study conducted in North Shewa zone of Oromia Region, Ethiopia in this regard. Hence, this study was designed to document the knowledge of medicinal plants usage, extraction, phytochemical screening, and assessment of antimicrobial activities of the herbal extracts.

\section{Materials and Methods}

\section{Study Areas and Design}

A cross sectional study was conducted from October, 2018 to June, 2019 at three selected districts of North Shewa zone, Oromia, Ethiopia. The zone is found at about 112 $\mathrm{km}$ north of Addis Ababa to Gojam main road. It is located between $9^{\circ} 05^{\prime}$ and $10^{\circ} 23^{\prime} \mathrm{N}$ latitude and $37^{\circ} 57^{\prime}$ and $39^{\circ}$ $28^{\prime} \mathrm{E}$ longitude. Its altitude ranges from about less than $1000 \mathrm{~m}$ to over $3540 \mathrm{~m}$. It has average annual rainfall ranging from $600-2000 \mathrm{~mm}$. The average minimum temperature is $10^{\circ} \mathrm{c}$ and maximum temperature is $32^{\circ} \mathrm{c}$ [10].

The total population of Fiche is 27,493 . The number of female and male population is 14,560 and 12,933 , respectively giving sex ratio of 113 females to 100 males. ${ }^{22}$ The average annual rainfall and temperature of the zone are $1075 \mathrm{~mm}$ and $20.3{ }^{\circ} \mathrm{C}$, respectively. The vegetation of the area is dominated by xerophylic plants. The population is highly used the traditional medicines to treat different diseases and disease conditions in the areas. It is also called the milk belt area where 206,000,000 liters of milk per year is produced and more $60 \%$ is supplied to Addis Ababa; because there are huge numbers of dairy cattle population with local $(352,216)$ and cross $(1,324,532)$ breed.

\section{Study Participants}

The study participants were traditional health practitioners/ healers who varied with age, sex, marital status, occupation, educational level and location in the selected districts.

\section{Sampling Methods}

A purposive sampling technique was used to select study districts, participants and plants based on the availability of traditional healers, proximity and agro-climatic conditions of the areas. In this study, 14 commonly used medicinal plant species were collected from the three districts.

\section{Key Informants}

In this study, 18 key informants (28-81 years old) were selected for in depth interview in the study districts based on the recommendations of local community leaders and knowledgeable elders. The selected healers were well known in the community due to experienced community based traditional health care services. Prior to the interview process, discussion was done with the informants through assistance of clan and local leaders to elaborate clearly the objective of the study. In depth interview of the key informants was done in the study areas. The interview was ensured by preparing key informants guide. ${ }^{17,19}$ 


\section{Observation}

In this survey, the key informants were also come together with the researchers for field guided walk in order to identify the origin of the plants where it grows, and provide local names. Then after, particular medicinal plants were collected with all ethno botanical data. Moreover, informant consensus was given to confirm the reliability of the information. Hence, each key informant was contacted at least twice and if the responses that were given at different time contradict to each other. Unreliable and not accepted or reliability of the information was confirmed by similar information given by different informants on the same issue.

\section{Plant Specimen Collection and Identification}

In this study, the collected plant specimens with the necessary recorded information both from wild and home garden were documented. Then the plants were taken to National Herbarium, Addis Ababa University for plant species identification using taxonomic keys of EthioEritrea Flora. The voucher specimen has been given starting from SIU Ethno Med/01-14/2018) as indicated in Table 1 and deposited in the National Herbarium. The identification was conducted by the botanist, Mr. Meleku Wondafrash Aytagid (Melaku.wondafrash@aau.edu.et), Addis Ababa University.

\section{Plant Material Preparation}

The fresh plant materials were collected from three selected districts of North Shewa zone, Oromia, Ethiopia; namely Girar Jarso, Degam and Warra Jarso. The leaf parts of Dodonea angustifolia L.f., Croton marostachyus Del., Calpurnia aurea (Ait.) Benth and Ostegia integrifolia Benth; and root part of Echinops kebericho Mesfin were collected, chopped into smaller pieces and shade dried in laboratory at room temperature without any exposure to direct sunlight. The dried plant materials were then powdered to facilitate easy solvent penetration. The powdered plant materials were stored in suitable containers until used for extraction. ${ }^{23,24}$

\section{Extraction of the Plant Material}

About $250 \mathrm{~g}$ of each powdered plant materials were sequentially extracted with an equal volume of about 2.5 liter hexane, chloroform and methanol using maceration technique for $24 \mathrm{hrs}$ with shaking. The extracts of each solvent was filtered first through a fresh cotton plug and then through fluted filter paper. The filtrates were concentrated by evaporation under reduced pressure using a Rota vapor at $40{ }^{\circ} \mathrm{C}$. The semidried extracts of each solvent were weighed and stored in refrigerator below $4{ }^{\circ} \mathrm{C}$ until used for antimicrobial activity.

\section{Phytochemical Screening of Secondary Metabolites}

Phytochemical screening tests for alkaloid, terpenoids, phenolic, flavonoid and saponin were conducted in all extracts by using standard procedures. ${ }^{25,26}$ Wagner's and Heger's reagents were used for alkaloid foam test for saponins, Magnesium chloride and Zinc chloride for

Table I Family, Scientific and Local Names of Ethno-Medicinal Plants Used for Treatment of Infectious Diseases in North Shewa Zone, Oromia, Ethiopia

\begin{tabular}{|c|c|c|c|c|}
\hline S.No & Specimen Voucher No & Family & Scientific Name & Local Name \\
\hline I. & SIU Ethno Med/0I/20I8 & Fabaceae & Acacia abyssinica Hochst. Ex Benth. & Qoree \\
\hline 2. & SIU Ethno Med/02/2018 & Fabaceae & Calpurnia aurea (Ait.) Benth & Ceekaa \\
\hline 3. & SIU Ethno Med/03/20I8 & Asteraceae & Laggera tomentosa (Sch.Bip.ex A Rich.) Olivo \& Hien & Dama Kasee \\
\hline 4. & SIU Ethno Med/04/20I8 & Utriticaceae & Urtica simensis steudel & Doobbii \\
\hline 5. & SIU Ethno Med/05/20I8 & Euphorbiaceae & Croton marostachyus Del. & Bakkanniisa \\
\hline 6. & SIU Ethno Med/06/2018 & Polygonaceae & Rumex nervosus Vahl & Embuachoo \\
\hline 7. & SIU Ethno Med/07/20I8 & Loganiaceae & Buddleja polystachya Fresen & Adaaddii \\
\hline 8. & SIU Ethno Med/08/20I8 & Myrtaceae & Eucalyptus globulus Labill & Baargamoo adi \\
\hline 9. & SIU Ethno Med/09/20I8 & Lamiaceae & Leonotis ocymifolia (Burm.f) Lwarsson & Bokkolluu \\
\hline 10. & SIU Ethno Med/I0/20I8 & Euphorbiaceae & Euphorbia tetracantha Rendle & Qincib \\
\hline II. & SIU Ethno Med/II/2018 & Sapindaceae & Dodonea angustifolia L.f. & Kitkittaa \\
\hline 12. & SIU Ethno Med/I2/20I8 & Ranunculaceae & Clematis simensis Fresen & Hidda fiitii \\
\hline 13. & SIU Ethno Med/I3/20I8 & Lamiaceae & Ostegia integrifolia Benth & Xunjiitii \\
\hline 14. & SIU Ethno Med/I4/20I8 & Asteraceae & Echinops kebericho Mesfin & Qabarichoo \\
\hline
\end{tabular}


flavonoids, acetic anhydride, and Ferric chloride for phenol test.

\section{Antimicrobial Activity}

The antimicrobial activity was carried out for five medicinal plant crude extracts. In this activity study, four reference bacterial strains, and one fungal strain were used. The antimicrobial assay was conducted using Agar disc diffusion method, ${ }^{27}$ and micro dilution broth assay. ${ }^{28}$ The microbial standard strains were obtained from Jimma University. In this study, bacterial strains such as Escherichia coli, Klebsiella pneumonia, Staphylococcus aureus, Pseudomonas aeruginosa; and fungal strain such as Candida albicans (spp) were considered for antimicrobial activity tests.

Antimicrobial activities of the crude extract were assessed using the disk diffusion method and the results were interpreted as per the Standards. ${ }^{29}$ Test solutions were prepared by dissolving $0.2,0.1$ and $0.05 \mathrm{~g}$ of plant extracts in Dimethylsulfoxide (DMSO) to achieve final stock concentrations of 200,100 and $50 \mathrm{mgmL}^{-1}$ respectively. Comparable microbial turbidity with standard 0.5 McFarland were prepared. ${ }^{30}$ The McFarland was prepared by mixing two solutions (solution A and B). Solution A has $1 \% \mathrm{v} / \mathrm{v}$ of sulphuric acid $\left(\mathrm{H}_{2} \mathrm{SO}_{4}\right)$ and solution $\mathrm{B}$ has $1 \% \mathrm{w} / \mathrm{v}$ of barium chloride $\left(\mathrm{BaCl}_{2}\right)$.

To get 0.5 McFarland standards, concentration equivalents to cell density of about $10^{7}-10^{8}$ cells $\mathrm{mL}$, an amount of $0.5 \mathrm{~mL} \mathrm{BaCl}_{2}$ of $1 \%$ solution A was mixed with 99.5 $\mathrm{mL} \mathrm{H}_{2} \mathrm{SO}_{4}$ of $1 \%$ solution B. A small volume of the turbid solution was transferred to a screw-cap bottle of the same types to use for preparing test and control inoculums. Culture containing test tube with approximately equal concentration or density with 0.5 McFarland standards was used for inoculation of media. The standard was used immediately, after shaking, and stored in a wellsealed container in a dark place at room temperature $\left(20-28{ }^{\circ} \mathrm{C}\right)$ when not use. When match with the standard, the standardize suspension and local isolates strains was swabbed by cotton swab onto the Muller-Hinton Agar (MHA) for bacteria, and Potato Dextrose agar for fungi (Oxoid) and allow to dry.

Sterilize standard paper discs $(6 \mathrm{~mm})$ was soaked with $30 \mu \mathrm{L}$ respective solution concentration of the extracts and air dry to evaporate the solvent and the discs were placed over the seeded plates at equidistance using forceps. Standard antibiotics disc, such as Gentamycin, and Contamazole were used as positive controls for microbial cultures. Thereafter, the plates were incubated at $37{ }^{\circ} \mathrm{C}$ for 18-24 hrs, room temperature and $48 \mathrm{hrs}$ for pathogenic fungi. The clear zones forming around each disc was measured using transparent ruler. Each experiment was carried out in triplicates.

The results of the antimicrobial susceptibility were interpreted according to the guidance described by Taylor et al. ${ }^{31}$ The mean \pm SD of the inhibition zone of each test sample was taken for evaluating the antimicrobial activity of the extracts.

\section{Data Analysis}

The collected data both from field and laboratory were entered and analyzed by using SPSS version 23 . Descriptive statistics like percent, figures and tables were used to summarize the collected ethno-medicinal data.

\section{Ethical Approval}

This study was approved by the Research Review Ethical Board of Salale University. The confidentiality of traditional property owners were completely maintained during processing of the data. Moreover, all the collected data from this study were not shared with third party out of researchers. Informed consent and permission were also obtained from the study participants and North Shewa zone Administration, respectively.

\section{Results}

A total of 10 major considerable medicinal plant families, and 14 plant species were identified and documented during the period in the study areas. Most of the habits of medicinal plants were shrub $(64.3 \%)$ followed by tree $(21.4 \%)$ and herb $(14.3 \%)$. The results indicated that the widely used plant parts for the preparation of the remedies were leaves $(71.4 \%)$ followed by root (14.3\%), shoot bud and bark with the same proportion (7.14\%). The traditional healers revealed that topical application (42.9\%) was most commonly used route of administration followed by inhalation (28.6\%). The majority of traditional healers were used plant remedies for the treatment of wound (35.7\%) followed by abdominal pain in the study areas. The healers indicated that Fabaceae Asteraceae, Lamiaceae and Euphorbiaceae plant families were the most commonly used plant remedies for the treatment of infectious diseases with equal proportion (14.3\%) (Tables 1 and 2 ). 
Table 2 Summary of Plant Families, Habits, Parts, Administration Routes and Diseases Treated Using Medicinal Plants in North Shewa Zone, Oromia, Ethiopia

\begin{tabular}{|c|c|c|c|c|}
\hline S.No & \multicolumn{2}{|c|}{ Description of Items } & Frequency & Percent \\
\hline \multirow[t]{10}{*}{ I. } & Plant family & Fabaceae & 2 & 14.3 \\
\hline & & Asteraceae & 2 & 14.3 \\
\hline & & Lamiaceae & 2 & 14.3 \\
\hline & & Euphorbiaceae & 2 & 14.3 \\
\hline & & Utriticaceae & I & 7.14 \\
\hline & & Polygonaceae & I & 7.12 \\
\hline & & Loganiaceae & I & 7.12 \\
\hline & & Myrtaceae & 1 & 7.14 \\
\hline & & Sapindaceae & I & 7.14 \\
\hline & & Ranunculaceae & I & 7.14 \\
\hline \multirow[t]{3}{*}{2.} & Plant habits & Shrub & 9 & 64.3 \\
\hline & & Tree & 3 & 21.4 \\
\hline & & Herb & 2 & 14.3 \\
\hline \multirow[t]{4}{*}{3.} & Plant parts & Leaf & 10 & 71.4 \\
\hline & & Root & 2 & 14.3 \\
\hline & & Bark & I & 7.14 \\
\hline & & Shoot bud & I & 7.14 \\
\hline \multirow[t]{3}{*}{4.} & Administration & Topical & 6 & 42.9 \\
\hline & routes & Inhalation & 4 & 28.6 \\
\hline & & Oral & 4 & 28.5 \\
\hline \multirow[t]{5}{*}{5.} & Diseases treated & Wound & 5 & 35.7 \\
\hline & & Abdominal & 3 & 21.4 \\
\hline & & Headache & 2 & 14.3 \\
\hline & & Ring worm & 2 & 14.3 \\
\hline & & Pneumonia & 2 & 14.3 \\
\hline
\end{tabular}

Note: Each percentage was calculated from the total 14 documented family plants.

\section{Phytochemical Screening Tests}

The phytochemical screening test results revealed that all solvent extracts of Calpurnia aurea (Ait.) Benth, Dodonea angustifolia L.f., Croton marostachyus Del., Echinops kebericho Mesfin and Ostegia integrifolia Benth contain at least one secondary metabolite. The phytochemical screening test of Dodonea angustifolia L.f.'s hexane and methanol extract contain excess amount of terpenoids and phenolic compounds, respectively. On the other hand, Ostegia integrifolia Benth's chloroform extract also contains excess amount of phenol. But, the alkaloid was negative in all the plant extracts (Table 3 ).

\section{Antibacterial Activity Test}

The antibacterial activity results of Dodonea angustifolia L.f., Croton marostachyus Del. and Calpurnia aurea (Ait.) Benth extracted with chloroform solvent showed equivalent inhibition zone against all bacterial strains as compared to standard drug, gentamicin. When compared with the inhibition zone of other extracts, Croton marostachyus Del.'s extract with chloroform showed highest antibacterial activity of $22.5 \pm 0.50 \mathrm{~mm}$ inhibition zone against $K$. pneumonia. On the other hand, the antibacterial activity of Echinops kebericho Mesfin and Ostegia integrifolia Benth extracted with chloroform showed less antibacterial activity than the antibacterial standard drug. However, the extracts of hexane and methanol solvent showed low inhibition zone as compared to chloroform solvents extracts (Table 4).

\section{Antifungal Activity Test}

The antifungal activity results of all extracts against $C$. albicans were revealed strong activity. Ostegia integrifolia Benth's extracted with chloroform showed inhibition zone of $23.3 \pm 0.29 \mathrm{~mm}$ which is greater than the antifungal activity of the standard drug, contamazole with $20.7 \pm$ $0.58 \mathrm{~mm}$ diameter of inhibition zone; and the antifungal activity results of Dodonea angustifolia L.f. and Calpurnia aurea (Ait.) Benth extracted with chloroform showed equivalent inhibition zone as compared to antifungal standard drug. However, the chloroform extracts of Croton marostachyus Del. and Echinops kebericho Mesfin showed less antifungal activity than the antifungal standard drug (Table 5).

\section{Discussion}

The current study documented the knowledge of traditional healers, and plant remedies used for the treatment of different diseases in the study areas. Euphorbiaceae, Lamiaceae and Sapindaceae were plant families that commonly practiced. This finding was in agreement with other studies that were conducted in different parts of Ethiopia. ${ }^{3,5,32-34}$

To assure the traditional usage of these plants, the phytochemical screening tests were conducted and the results indicated that Dodonea angustifolia L.f.'s hexane and methanol extract contain excess amount of terpenoids and phenolic compounds, respectively. Ostegia integrifolia Benth's chloroform extract also contains excess amount of phenol. This indicates that the secondary metabolites exist in the plant extracts are responsible for defenses against pathogenic microbes, and thus, support the traditional usage of the plant remedies for the treatments of infectious diseases. $^{35-38}$ 
Table 3 Phytochemical Screening Test Results Selected Ethno-Medicinal Plants

\begin{tabular}{|c|c|c|c|c|c|c|}
\hline S.No & Scientific Name & Phytochemicals & Tests & Hexane extract & Chloroform extract & Methanol extract \\
\hline \multirow[t]{5}{*}{1} & \multirow[t]{5}{*}{ Calpurnia aurea (Ait.)Benth } & Alkaloid & Wagner's test & - & - & - \\
\hline & & Terpenoids & Salkowski's test & + & _ & _ \\
\hline & & Phenolic & Ferric chloride & _ & - & + \\
\hline & & Flavonoid & $\mathrm{NaOH}$ test & _ & + & _ \\
\hline & & Saponin & Foam test & - & + & + \\
\hline \multirow[t]{5}{*}{2} & \multirow[t]{5}{*}{ Dodonea angustifolia L.f. } & Alkaloid & Wagner's test & - & - & - \\
\hline & & Terpenoids & Salkowski's test & ++ & - & - \\
\hline & & Phenolic & Ferric chloride & - & - & ++ \\
\hline & & Flavonoid & $\mathrm{NaOH}$ test & + & + & - \\
\hline & & Saponin & Foam test & - & - & + \\
\hline \multirow[t]{5}{*}{3} & \multirow[t]{5}{*}{ Croton marostachyus Del. } & Alkaloid & Wagner's test & - & - & - \\
\hline & & Terpenoids & Salkowski's test & + & + & _ \\
\hline & & Phenolic & Ferric chloride & - & - & + \\
\hline & & Flavonoid & $\mathrm{NaOH}$ test & - & - & + \\
\hline & & Saponin & Foam test & - & + & - \\
\hline \multirow[t]{5}{*}{4} & \multirow[t]{5}{*}{ Echinops kebericho Mesfin } & Alkaloid & Wagner's test & - & - & - \\
\hline & & Terpenoids & Salkowski's test & + & - & - \\
\hline & & Phenolic & Ferric chloride & - & - & + \\
\hline & & Flavonoid & $\mathrm{NaOH}$ test & + & - & - \\
\hline & & Saponin & Foam test & + & + & - \\
\hline \multirow[t]{5}{*}{5} & \multirow[t]{5}{*}{ Ostegia integrifolia Benth } & Alkaloid & Wagner's test & - & - & - \\
\hline & & Terpenoids & Salkowski's test & + & - & - \\
\hline & & Phenolic & Ferric chloride & - & ++ & + \\
\hline & & Flavonoid & $\mathrm{NaOH}$ test & - & - & + \\
\hline & & Saponin & Foam test & _ & - & _ \\
\hline
\end{tabular}

Notes: $-=$ Not present; $+=$ Present; $++=$ highly present.

All the plant extracts showed antimicrobial activities against all bacterial and fungal strains. Chloroform extracts of Croton marostachyus Del.'s showed higher antibacterial activity than the standard drug against $K$. pneumonia. On the other hand, chloroform extracts of Dodonea angustifolia L.f., Croton marostachyus Del. and Calpurnia aurea (Ait.) Benth showed equivalent inhibition zone against all bacterial strains as compared to standard drug, gentamicin. However, Echinops kebericho Mesfin and Ostegia integrifolia Benth extracts had lower antibacterial activity. All the extracts could be considered as broad spectrum, and had promising inhibition against $E$. coli, K. pneumoniae, S.aureus, and $P$. aeruginosa. Similarly, the antifungal activities of all chloroform extracts were also found to be comparable with standard antifungal drug. The antifungal activities of all extracts against $C$. albicans were also revealed promising activity as compared to antifungal standard drug, contamazole. The antibacterial activity of all chloroform extracts 'against $K$. pneumonia were found to be similar. The 


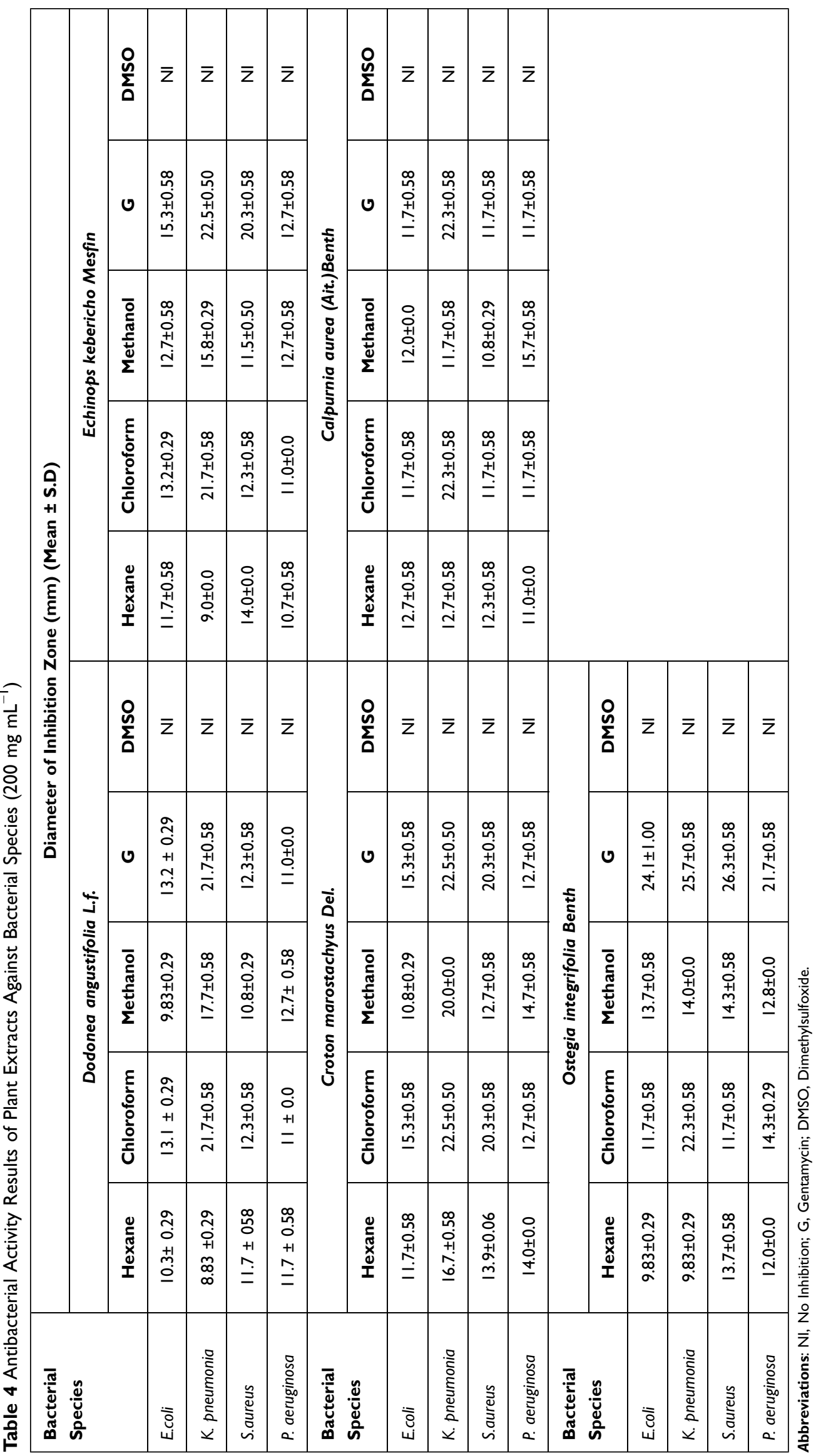


Table 5 Antifungal Activity Results of Plant Extracts Against Fungal Species (200 mg mL ${ }^{-1}$ )

\begin{tabular}{|c|c|c|c|c|c|c|c|c|c|c|}
\hline \multirow{3}{*}{$\begin{array}{l}\begin{array}{l}\text { Fungal } \\
\text { Species }\end{array} \\
\text { C. albicans }\end{array}$} & \multicolumn{10}{|c|}{ Diameter of Inhibition Zone $(\mathrm{mm})$ (Mean \pm S.D) } \\
\hline & \multicolumn{5}{|c|}{ Dodonea angustifolia L.f. } & \multicolumn{5}{|c|}{ Echinops kebericho Mesfin } \\
\hline & Hexane & Chloroform & Methanol & C & DMSO & Hexane & Chloroform & Methanol & C & DMSO \\
\hline & $10.7 \pm 0.58$ & $13.7 \pm 0.58$ & $11.7 \pm 1.15$ & $13.7 \pm 0.58$ & $\mathrm{NI}$ & $13.0 \pm 0.58$ & $13.7 \pm 0.58$ & $13.0 \pm 1.00$ & $15.0 \pm 0.0$ & $\mathrm{NI}$ \\
\hline & \multicolumn{5}{|c|}{ Croton marostachyus Del. } & \multicolumn{5}{|c|}{ Calpurnia aurea (Ait.)Benth } \\
\hline & Hexane & Chloroform & Methanol & C & DMSO & Hexane & Chloroform & Methanol & C & DMSO \\
\hline & $12.0 \pm 1.00$ & $28 \pm 0.29$ & $21.0 \pm 1.00$ & $28.3 \pm 3.10$ & $\mathrm{NI}$ & $12.3 \pm 0.58$ & $23.3 \pm 1.15$ & $14.3 \pm 1.15$ & $23.3 \pm 1.15$ & $\mathrm{NI}$ \\
\hline & \multicolumn{5}{|c|}{ Ostegia integrifolia Benth } & & & & & \\
\hline & Hexane & Chloroform & Methanol & C & DMSO & & & & & \\
\hline & $18.0 \pm 0.0$ & $23.3 \pm 0.29$ & $13.7 \pm 0.58$ & $20.7 \pm 0.58$ & $\mathrm{NI}$ & & & & & \\
\hline
\end{tabular}

Abbreviation: C, Contamazole.

higher and comparable antibacterial activity of chloroform extracts might be due to the possible extraction of active secondary metabolites from plants by chloroform following like dissolve like principle. ${ }^{39}$

Therefore, the antimicrobial screening results also support the traditional usage of these plants for the treatments of infectious diseases in the study areas, and similar research findings were reported in Pakistan, ${ }^{38}$ in different part of Ethiopia such as Tigray, ${ }^{40}$ Gozamin Wereda ${ }^{41}$ Ankober district, ${ }^{19}$ Ada'a district, ${ }^{20}$ and around Fitche district. ${ }^{21}$

This study was limited to the crude extractions of four plants and their antimicrobial activity against three bacterial and one fungal reference strains. Moreover, the isolation of active compounds from the extracts was not done which is actually responsible for the antimicrobial activities.

\section{Conclusions}

Medicinal plants from the Euphorbiaceae, Lamiaceae, and Sapindaceae families have been used to treat a variety of diseases in the study area. The phytochemical screening test revealed the presence of secondary metabolites and confirms the traditional uses of the studied plants for the treatments of diseases. The study indicated that chloroform extracts showed comparable antimicrobial activities with the standard drugs, and the result obtained here is an indicator for the potential sources of the studied medicinal plants as an antimicrobial agent; and thus, further in vitro and in vivo antimicrobial activity studies of chloroform extracts against $K$. pneumonia bacterial and C.albicans fungal strains were recommended. Isolation of active compounds from chloroform extracts was also recommended.

\section{Data Sharing Statement}

All required data are included in this paper.

\section{Ethics Approval and Consent to Participate}

Ethics approval for this study was obtained from Salale University. Verbal consent was obtained from all study participants before the data collection started and privacy was secured. Since all study participants are above age 18 years old and highly secured information is not needed the verbal consent was obtained, and the ethics committee of Salale University approved this procedure.

\section{Acknowledgment}

The study participants and all individuals who render help during the study period are highly acknowledged.

\section{Author Contributions}

All authors made a significant contribution to the work reported, whether that is in the conception, study design, execution, acquisition of data, analysis and interpretation, or in all these areas; took part in drafting, revising or critically reviewing the article; gave final approval of the version to be published; have agreed on the journal to which the article has been submitted; and agree to be accountable for all aspects of the work.

\section{Funding}

The authors would like to thank Salale University for financial and logistic support to conduct this research. 


\section{Disclosure}

The authors had declared no conflicts of interest for this work.

\section{References}

1. Abera B. Medicinal plants used in traditional medicine by Oromo people, Ghimbi District, Southwest Ethiopia. J Ethnobiol Ethnomed. 2014;10(1):40. doi:10.1186/1746-4269-10-40

2. Sathiya M, Muthuchelian K. Phytochemical investigation and antibacterial screening of ethanolic leaf extract of Sapindus emarginatus vahl. Ethnobot Leafl. 2008;1:121.

3. Birhanu T, Abera D. Survey of ethno-veterinary medicinal plants at selected Horro Gudurru Districts, Western Ethiopia. Afr J Plant Sci. 2015;9(3):185-192. doi:10.5897/AJPS2014.1229

4. Atnafu H, Awas T, Alemu S, Wube S. Ethnobotanical study of medicinal plants in Selale Mountain ridges, North Shewa Zone, Ethiopia. Biodivers Int J. 2018;2(6):567-577. doi:10.15406/ bij.2018.02.00114

5. Tamiru F, Terfa W, Kebede E, Dabessa G, Kumar Roy R, Sorsa M. Ethno knowledge of plants used in veterinary practices in Dabo Hana District, West Ethiopia. J Med Plant Res.2013;7(40):2960-2971. doi:10.5897/JMPR2013.5225

6. Abdillahi HS, Stafford GI, Finnie JF, Staden JV. Ethnobotany, phytochemistry and pharmacology of Podocarpus sensus latissimo (S.I.) S Afr J Bot. 2010;76(1):1-24. doi:10.1016/j.sajb.2009.09.002

7. Graham LP. An Introduction to Medicinal Chemistry. 5th ed. United Kingdom; 2013. Available from: https://www.academia.edu/ 36903466/

8. Stuart BEL, Bonnie M. Antibacterial resistance worldwide: causes, challenges and responses. Nat Med. 2004;10(S12):122-129. doi: $10.1038 / \mathrm{nm} 1145$

9. Parekh J, Chanda SV. In vitro antimicrobial activity and phytochemical analysis of some Indian medicinal plants. Turk $J$ Biol. 2007;31:53-58.

10. John RST, Collins BK, Paul JW. Medicinal plants used by traditional medicine practitioners in the treatment of tuberculosis and related ailments in Uganda. $J$ Ethnopharmacol. 2010;127(1):130-136. doi:10.1016/j.jep.2009.09.035

11. Sebua S, Alfred M. Medicinal plants used for the treatment of tuberculosis by Bapedi traditional healers in three districts of the Limpopo Province, South Africa. Afr J Tradit Complement Altern Med. 2013;10(2):316-323. doi:10.4314/ajtcam.v10i2.17

12. Lawal IO, Grierson DS, Afolayan AJ. Phytotherapeutic information on plants used for the treatment of tuberculosis in Eastern Cape Province, South Africa. Hindawi Publishing Corporation. Evid Based Complement Alternat Med. 2014;2014:1-11. doi:10.1155/ 2014/735423

13. Joseph MN, Regina AO, Alexander KN, Dorothy YM, Phyllis GAA. Medicinal plants used to treat TB in Ghana. Int $J$ of Mycobacteriol. 2015;4(2):116-123. doi:10.1016/j.ijmyco.2015.02.003

14. Giday M, Teklehaymanot T, Animut A, Mekonen Y. Medicinal plants of the Shinasha, Agewi-Awi and Amhara peoples in northwest Ethiopia. $J$ Ethnopharmacol. 2007;110(3):516-525. doi:10.1016/j. jep.2006.10.011

15. Giday M, Asfaw Z, Woldu Z. Medicinal plants of the Meinit ethnic group of Ethiopia: an ethnobotanical study. $J$ Ethnopharmacol. 2009;124(4):513-521. doi:10.1016/j.jep.2009.05.009

16. Assefa B, Glatzel G, Buchmann C. Ethnomedicinal uses of Hagenia abyssinica (Bruce) J.F. Gmel. among rural communities of Ethiopia. $J$ Ethnobiol Ethnomed. 2010;6(1):20. doi:10.1186/1746-4269-6-20

17. Mesfin F, Demissew S, Teklehaymanot T. An ethnobotanical study of medicinal plants in Wonago Woreda, SNNPR, Ethiopia. J Ethnobiol Ethnomed. 2009;5(1):28. doi:10.1186/1746-4269-5-28
18. Teklehaymanot T, Gida M. Ethnobotanical study of wild edible plants of Kara and Kwego semi-pastoralist people in Lower Omo River Valley, Debub Omo Zone, SNNPR, Ethiopia. J Ethnobiol Ethnomed. 2010;6(1):23. doi:10.1186/1746-4269-6-23

19. Ermias Lulekal E, Asfaw Z, Kelbessa E, Van Damme P. Linking ethnobotany, herbaria and flora to conservation: the case of four angiosperm families at the national herbarium of Ethiopia. $J$ East Afr Nat Hist. 2012;101(1):99-125. doi:10.2982/028.101.0106

20. Alemayehu K, Zemede A, Ensermu K. Ethnobotany of medicinal plants in Ada'a District, East Shewa Zone of Oromia Regional State, Ethiopia. J Ethnobiol Ethnomed. 2015;11(1):25. doi:10.1186/s13002015-0014-6

21. Enyew A, Asfaw Z, Kelbessa E, Raja N. Ethnobotanical study of traditional medicinal plants in and around Fitche district, Central Ethiopia. Curr Res J Biol Sci. 2014;6(4):154-167. doi:10.19026/crjbs.6.5515

22. CSA. Federal Democratic Republic of Ethiopia Central Statistical Agency, estimate population of North Shewa Zone, Oromia, Ethiopia, Addis Ababa, Ethiopia; 2018-19.

23. Edwards S. Ecology and Conservation Status of Medicinal Plants for Sustainable Use of Medicinal Plants in Ethiopia. 2001:46-55.

24. Hedberg I, Kelbessa E, Edwards S, Demissew S, Persson E. Gentianaceae to Cyclocheiaceae. Flora of Ethiopia and Eritrea. Sweden: National herbarium Addis Ababa, Ethiopia and Uppsala; 2006:5.

25. Abdissa D, Faye G, Fayera M, Demissie S. Extraction and isolation of compound from roots of Kniphofia pumila, and its antibacterial activities in combination with zinc chloride. Walailak $J$ Sci Technol. 2020;17(7):631-638. doi:10.48048/wjst.2020.6163

26. Obdoni BO, Ochuko PO. Phytochemical studies and comparative efficacy of the crude extract of some homostatic plants in Edo and Delta States of Nigeria. Glob J Pure Appl Sci. 2012;8(2):203-208. doi:10.4236/ajps.2017.82021

27. Mukram MM, Lim YM, Mohidin A, Nashriyah M, Nordin HL, Abdul MA. Non cytotoxic and antitumour-promoting activities of garcinia acid esters from Garcinia atroviridis Griff. ex T. Anders (Guttiferae). Evid Based Complement Alternat Med. 2014;2012:5. Article ID 829814. doi:10.1155/2012/829814

28. Komuraiah A, Bolla K, Rao KN, Ragan A, Raju VS, Singara CMA. Antibacterial studies and phytochemical constituents of South Indian Phyllanthus species. Afr J Biotechnol. 2009;8(19):4991-4995.

29. Tsegaye S, Ketema B, Tsige K. The growth potential and antimicrobial susceptibility patterns of Salmonella species and Staphylococcus aureus isolated from mobile phones of food handlers and health care workers in Jimma Town, Southwest Ethiopia. Afr J Microbiol Res. 2016;10(8):254-259. doi:10.5897/AJMR2015.7621

30. Akhtar N, Ul-Haq I, Mirza B. Phytochemical analysis and comprehensive evaluation of antimicrobial and antioxidant properties of 61 medicinal plant species. Arab J Chem. 2018;11(8):1223-1235. doi:10.1016/j.arabjc.2015.01.013

31. Taylor C, Abbey BS, Eszter D. What's New from the CLSI Subcommittee on Antimicrobial Susceptibility Testing M100, 29th Edition. Clin Microbiol Newsl. 2019;41(23):203-209. doi:10.1016/j. clinmicnews.2019.11.002

32. Akil U, Birhanu T, Redwan M, Sado E, Abera D. Ethno-medicinal plants at selected districts of Harari Regional State, Eastern Ethiopia. Ethiop Vet J. 2016;20(1):1-22. doi:10.4314/evj.v20i1.1

33. Gebrezgabiher G, Kalayou S, Sahle S. An ethnobotanical study of medicinal plants in Woredas of Tigray region, Northern Ethiopia. Int J Biodivers Conserv. 2013;5(2):89-97.

34. Yigezu Y, Haile DB, Ayen YW. Ethno veterinary medicines in four districts of Jimma zone, Ethiopia: cross sectional survey for plant species and mode of use. BMC Vet Res. 2014;10(1):76. doi:10.1186/ 1746-6148-10-76

35. Mengiste B, Hagos Y, Moges F, Tassew H, Tadesse G, Teklu A. In vitro antibacterial screening of extracts from selected Ethiopian medicinal plants. Momona Ethiop J Sci. 2014;6(1):102-110. doi:10.4314/ mejs.v6i1.102418 
36. Fentahun M, Ayele Yilkal B, Amsalu N, Alemayehu A, Amsalu G. Antibacterial evaluation and phytochemical analysis of selected medicinal plants against some pathogenic enteric bacteria in Gozamin District, Ethiopia. J Pharmacovigil. 2017;5(5):2-6. doi:10.4172/ 2329-6887.1000244

37. Sisay M, Bussa N, Gashew T, Mengistu G. Investigating in vitro antibacterial activities of medicinal plants having Folkloric Repute in Ethiopian traditional medicine. J Evid Based Integr Med. 2019;24:19. doi:10.1177/2515690X19886276

38. Khan N, Abbasi AM, Dastagir G, et al. Ethnobotanical and antimicrobial study of some selected medicinal plants used in Khyber Pakhtunkhwa (KPK) as a potential source to cure infectious diseases. BMC Complement Altern Med. 2014;14(1):122. doi:10.1186/14726882-14-122
39. Phan-Canh T, Le-thi TT, Hoang TVH, TuAnh N. DPPH-scavenging and antimicrobial activities of Asteraceae medicinal plants on uropathogenic bacteria. Evid Based Complement Alternat Med. 2020;2020:9. Article ID 7807026. doi:10.1155/2020/7807026

40. Kalayou S, Haileselassie M, Gebre-egziabher G, et al. In-vitro antimicrobial activity screening of some ethnoveterinary medicinal plants traditionally used against mastitis, wound and gastrointestinal tract complication in Tigray Region, Ethiopia. Asian Pac J Trop Biomed. 2012;2(7):516-522. doi:10.1016/S2221-1691(12)60088-4

41. Amsalu N, Bezie Y, Fentahun M, Alemayehu A, Amsalu G. Use and conservation of medicinal plants by indigenous people of Gozamin Wereda, East Gojjam Zone of Amhara Region, Ethiopia: an ethnobotanical approach. Evid Based Complement Alternat Med. 2018;10:23. Article ID 2973513. doi:10.1155/2018/2973513

\section{Publish your work in this journal}

Infection and Drug Resistance is an international, peer-reviewed openaccess journal that focuses on the optimal treatment of infection (bacterial, fungal and viral) and the development and institution of preventive strategies to minimize the development and spread of resistance. The journal is specifically concerned with the epidemiology of antibiotic resistance and the mechanisms of resistance development and diffusion in both hospitals and the community. The manuscript management system is completely online and includes a very quick and fair peerreview system, which is all easy to use. Visit http://www.dovepress.com/ testimonials.php to read real quotes from published authors. 